\title{
Andean roots and tubers as sources of functional foods
}

\author{
Eduardo O. Leidi ${ }^{*}$, Alvaro Monteros Altamirano ${ }^{2}$, Geovana Mercado ${ }^{3}$,Juan Pablo \\ Rodriguez ${ }^{4}$, Alvaro Ramos ${ }^{1}$, Gabriela Alandia ${ }^{5}$, Marten Sørensen ${ }^{5}$, Sven-Erik \\ Jacobsen $^{5}$ \\ ${ }^{1}$ Department of Plant Biotechnology, IRNAS-CSIC, E-41012 Seville, Spain. \\ ${ }^{2}$ Instituto Nacional de Investigaciones Agropecuarias, Departamento Nacional de \\ Recursos Fitogenéticos, Estación Experimental Santa Catalina, Quito, Ecuador. \\ ${ }^{3}$ Facultad de Agronomía, Universidad Mayor de San Andrés, La Paz, Bolivia. \\ ${ }^{4}$ Research and Innovation Division, International Center for Biosaline Agriculture, P.O. \\ Box 14660, Dubai, United Arab Emirates \\ ${ }^{5}$ University of Copenhagen, Faculty of Science, Dep. of Plant and Environmental \\ Sciences, DK-2630 Taastrup, Denmark. \\ ${ }^{*}$ Corresponding author. \\ E-mail address: eo.leidi@csic.es
}

\section{Summary.}

There are many valuable plant species improved by ancient cultures and cultivated locally but of very limited expansion worldwide. Some are considered neglected and underutilized species, such as the root and tuber crops from the Andes. They constitute traditional energy sources basic for the food security in the region but they also are great source of functional foods and there is a traditional associated knowledge on their nutraceutical properties. In this review, we focus on a few species (ahipa, arracacha, mashua, yacon) evaluated in the LATINCROP project which gathered information regarding their conservation status, cultivation practices and traditional uses and to promote new culinary uses. At the same time, this review covers the latest studies on the food components and their possible nutraceutical properties which may increase the public awareness to promote their adoption.

Keywords: ahipa, arracacha, mashua, yacon, functional foods, food security 


\section{Introduction.}

Reassessing neglected and underutilized crops for maintaining food security and improving human nutrition worldwide might be an excellent opportunity to recover forgotten crops at risk of extinction (Hernandez Bermejo and Leon, 1994; Jacobsen et al., 2013; Padulosi et al., 2014; Jacobsen et al., 2015). Global initiatives like the declaration of 2013 as the international year of quinoa (FAO, 2013; Bazile et al., 2016) boosted public knowledge of an important seed crop already adopted by the vegetarian, vegan and consumers of organic products in the world. But many other crops whose valuable diversity is maintained by local producers and consumers lay far behind with respect to world awareness (Hernandez Bermejo and Leon, 1994; Gahukar, 2014). In countries of the Andean region several important root and tuber (ART) crops are produced being part of the traditional diet. Among these are mashua (Tropaeolum tuberosum Ruíz \& Pav.), arracacha (Arracacia xanthorrhiza Bancr.), ahipa (Pachyrhizus ahipa (Wedd.) Parodi (Wedd.) Parodi), and yacon (Smallanthus sonchifolius (Poepp.) H.Rob.), which in spite of their nutritional benefits, seldom reach food markets. Thus, as only limited and discontinuous amounts are offered and with the adoption of other food energy sources in continuous supply by city dwellers, e.g. from wheat-derived pasta to potatoes, producers are discouraged of commercialization and mostly produce only for self-consumption. Furthermore, there are several other Andean roots and tuber species, like the papalisa (Ullucus tuberosus $\underline{\text { Caldas), oca }}$ (Oxalis tuberosa Molina), maca (Lepidium meyenii Walp.), mauka (Mirabilis expansa (Ruíz \& Pav.) Standl.), and achira (Canna indica L.), with outstanding nutritional properties. These roots and tuber crops contain mostly sources of energy in the forms of starch and sugars, with little protein content, but additionally they may supply minerals, vitamins, dietary fibers and antioxidants, all food compounds with associated health benefits. However, scientific research regarding their benefits, from agrobiodiversity conservation to food security, is scarce because of attention and research funds have been driven to the most popular sources for energy and proteins like rice, maize, wheat, potatoes and soybean (Jacobsen et al., 2013; Padulosi et al., 2014). Moreover, all the knowledge regarding the neglected and underutilized species is at present dispersed and very restricted locally as part of a rich traditional heritage (FAO, 2012). Local initiatives for gathering information about ART cultivation, have been remarkable in some countries (Barrera et al., 2004; Aruquipa et al., 2016ab; Bosque et al., 2016). Some international approaches led the way to improve 
conservation, management and innovative uses, such as implemented in the Latincrop project (www.Latincrop.org).

The concept of functional foods refers to the food products that apart from being a source of nutritional compounds, provide other health benefits to consumers (Aluko, 2012). The content of bioactive compounds in the ARTs and their nutraceutical properties have not been fully tested yet, and the study of the physiological and molecular mechanisms behind their benefits is greatly needed. However, these foods have lately attracted the attention of consumers in several countries. In this sense, food crops that hold distinctive health-improving properties, have an added value for both consumers and producers.

The EU funded Latincrop project (2014-2017) was an important initiative for gathering information on the biodiversity and utilization practices of several grain and root crops originating from the Andean region. Some of the most relevant outputs of the Latincrop project include mapping and characterizations of these species and a collection of both traditional and novel recipes (Melting Pot Bolivia, 2017) which adds more interest in the culinary uses of these crops, together with similar national or international initiatives (Villacrés and Ruíz, 2002; FAO, 2013).

In this article we aim to present a review of the current knowledge about the potential functional foods from arracacha, yacon, ahipa and mashua (see Supplementary Table 1 for vernacular names). The ARTs that will be described are an example of some of the least developed species, but with a significant potential for increased production, consumption and market sale. Hence we present a review including locally published information and studies compiled by the Latincrop project and other independent local scientists and institutions.

\section{Arracacha (Arracacia xanthorrhiza)}

The arracacha is a tuberous root (Fig. 1) grown in the Andean region used for the preparation of soups, stews and purees, and for making bread, cakes and drinks (Hermann, 1997; García and Pacheco-Delahaye, 2010; Albano et al., 2014). It is popular in several South American countries (Bolivia, Brazil, Colombia, Peru, Ecuador, and Venezuela) for feeding babies and elderly people. The plant belongs to the Apiaceae (syn. Umbelliferae) family, and it makes several storage roots which may weigh from $0.3 \mathrm{~kg}$ to more than $1 \mathrm{~kg}$ per plant (Hermann, 1997). It is cultivated at an 
altitude of between 1500 to $3200 \mathrm{~m}$ from the North of Chile to Venezuela, but also in the Southeast of Brazil (Hermann, 1997; Tapia and Fries, 2007). Yield may reach up to $20 \mathrm{t} \mathrm{ha}^{-1}$ (Hermann, 1997). More recent yield estimates for Venezuelan cultivars were 2.7-22 $\mathrm{t} \mathrm{ha}^{-1}$ (Jaimez et al., 2008), and 7-8 $\mathrm{t} \mathrm{ha}^{-1}$ for arracacha both intercropped and monocultured in Brazil (Heredia-Zárate et al., 2008).

Among the main nutritional properties of arracacha is the high starch content (25\%) (Table 1) and vitamins A, B and C (Hermann, 1997; Reyes-García et al., 2009). There is also a reported high content of $\mathrm{Ca}, \mathrm{P}$ and $\mathrm{Fe}$ in arracacha roots (Herman, 1997; Espín et al., 2004; Monge, 2008), but in a recent study on mineral composition made with samples collected in Bolivia and Peru, the content was not higher in this species in comparison with mashua and yacon (Table 1). By cooking, arracacha roots lose antioxidant compounds like phenolics and carotenoids. A short-time boiling conserves these functional components better than cooking in electrical, gas or microwave oven (Pedreschi et al., 2011). Arracacha may be used for starch extraction, and arracacha starch properties provide particular uses in the food industry (García and Pacheco-Delahaye, 2010; Albano et al., 2014). In fact, the potential industrial use of arracacha starch has led to a complete characterization of its physico-chemical and rheological properties (Santacruz et al., 2002, 2003; Albano et al., 2014). The arracacha starch has $17-21 \%$ of amylose (depending on variety), which is lower than the contents found in potato and mashua (Espín et al., 2004). It makes arracacha starch highly digestible and thus a recommended energy supply for babies and elderly people.

There is a significant variability in root dry matter and carotenoid contents in arracacha (Hermann, 1997). The variation in carotenoid concentration shows that its roots might be a potential dietary source of pro-vitamin A. The protein concentration in the roots of arracacha is low, around 4-5\% on dry matter basis (Hermann, 1997; Espín et al., 2004). Although arracacha protein is easily digested, it presents a lack in some essential amino acids like tryptophan, which reduces its biological quality (Espín et al., 2004).

\section{Crop History}

It is believed that arracacha is the oldest plant cultivated in America. In Ecuador, it has been cultivated since $500 \mathrm{BC}$ (Estrella, 1988), and other references track its cultivation back to pre-colonial times (Hodge, 1954) where it was found throughout the Inca empire. The discovery of arracacha pollen in coprolites on the archeological site of Guarmey in Peru set the crop at a time between 3,200-2,200 BC (Weir and Bonavia, 1985).

Traditional production and consumption 
Arracacha is cultivated by micro-producers (whose properties range from 0.5 ha 2400 ha, based on annual per capita consumption, while for Ecuador there were 340 ha of production at national level in 1995 (Barrera, et al., 2004). In Ecuador there are white, yellow and purple varieties (Tapia et al., 2004). The crop of arracacha is distributed in the inter-Andean region, with a greater diversity of ecotypes in the southern provinces of Cañar, Azuay and Loja (Mazón et al., 1996). The largest commercial production occurs in Northern Ecuador in the provinces of Pichincha and Tungurahua (Mazón et al., 1996; Espinosa et al., 1996). In Bolivia, arracacha is produced in the inter-Andean valleys and tropical regions of La Paz and Cochabamba between 1500-2500 $\mathrm{m}$ a.s.l. The greatest diversity however, can be found in the Yungas region of La Paz, in the communities of Coroico (near the Amazon basin). Up to ten different varieties have been reported such as yellow, white, green-yellow, purple-yellow, white yellow, creamy among others (LATINCROP, 2017).

The yield of the Ecuadorian arracacha collection (109 accessions) averages 8.4 t ha $^{-1}$ (Mazón, 1993). In Intag (North Ecuador), arracacha is associated with legumes such as peas (Espinosa et al., 1996). In San José de Minas, a white ecotype is commercially sown in monoculture but when it is destined for self-consumption it is associated with sambo, cabbage, cassava, peas, beans, corn, etc. (Espinosa et al., 1996). Tapia et al. (1996) also found associations with cassava, sugarcane and tomato tree for collections located between 1200 and 1300 meters above sea level. The crop is also rotated with potato, maize, leguminous, etc. or interplanted (Hodge, 1954).

In Bolivia the cultivation of arracacha is associated with potato in furrows. It is sown at the same time as potato, near the rainy season. Potato is harvested before arracacha due to its shorter cycle (8 months). In the inter-Andean valleys, yacon and mashua are also sown but cultivated mostly for self-consumption. Only when there is surplus, it is sold or exchanged at local fairs. In Irupana and Coroico (Bolivian Yungas), arracacha in monoculture occupies small plots and most of the production is intended for commercialization at La Paz or Cochabamba city markets (LATINCROP, 2017).

In Ecuador, the urban consumption of arracacha roots is restricted to the main cities such as Quito, Guayaquil and Cuenca (Mazón et al., 1996).

In Colombia, arracacha leaves are consumed in soups (Hodge, 1954). Several recipes have been compiled to encourage consumption (Villacrés et al., 2002). The trunks are consumed by pigs and leaves by cattle (Espinosa et al., 1996).

In Bolivia the consumption is traditionally greater near the end of the year where it is used to accompany different New Year dishes with pork or fish. In Coroico different dishes are prepared with each different variety of arracacha being the purple yellow 
and white cream varieties the most popular in the kitchen. In confectionery, the yellow variety is used for its flavor and smell, which are very strong, for desserts. The boiled roots are also consumed as a dessert after lunch or as a snack during the morning. In other areas it is used in many dishes such as arracacha soups, stews and pastries or as a replacement of potatoes.

Medicinal uses

There is a widespread belief that arracacha has medicinal properties for a variety of uses such as post-partum applications to facilitate placental elimination (Hermann et al., 1997; Tapia et al., 1996). In aboriginal medicine, the cooked and crushed root is applied as anti-inflammatory and antiseptic poultice, and also holds diuretic properties and anti-diarrheal (Estrella, 1988). The fresh roots juice makes a mild purgative and when mixed with bread-crumbs produces a poultice used to alleviate painfully swollen breasts (Hodges, 1954).

\section{Yacon (Smallanthus sonchifolius)}

The sweet and juicy yacon roots have a high water content and fructose together with high concentration of fructooligosaccharides (FOS) (Grau and Rea, 1997; Seminario et al., 2003; Espín et al., 2004; Coll Aráoz et al., 2014; Jiménez and Sammán, 2014). Traditionally, it has been used as a fruit (Grau and Rea, 1997; Huaycho et al., 2016) while at present it is used for preparation of syrups, yoghurts, ice creams and cakes (Seminario et al., 2003; Flores, 2010). The root weight per plant ranges from 0.21 to $0.27 \mathrm{~kg}$ (Ramos Zapana and Arias Arroyo, 2010) and yacon root yield vary from 28 to 100 t ha $^{-1}$ (Grau and Rea, 1997; Fernández et al., 2006; Tokita et al., 2015). In the Andes, yacon is grown mostly for peasants' consumption from North Argentina to Ecuador (Grau, 1997). It is becoming increasingly popular for its nutraceutical properties in Asian countries (Japan) (Koike et al., 2007) and New Zealand where it is being cropped commercially (Douglas et al., 2005ab).

In Table 1, the composition of yacon is presented in comparison with ahipa, arracacha and mashua. The concentration of soluble sugars, glucose, fructose and sucrose is high, and fructose clearly is the main stored sugar (Ohyama et al., 1990). The concentration of soluble sugars and FOS, linear polysaccharides formed by $\beta(1-2)$ linked fructose units, depends on the accession, harvest time and postharvest treatment (Fukai et al., 1997; Lachman et al., 2004; Chavarry Torres, 2007). In comparison with arracacha and mashua, both of which mostly store starch, yacon reserves carbohydrates as FOS with different degree of polymerization (DP) (Grau and 
Rea, 1997; Jiménez and Sammán, 2014). A survey using yacon roots from diverse concentration of mono- (glucose, fructose) and disaccharides (sucrose) (Hermann et al., 1999). However, later reports have shown a significant variation in FOS content (6 to 65\%) (Campos et al., 2012) and composition (low or high DP FOS) between accessions (Dwivedi et al., 2014; Coll Aráoz et al., 2014), which might provide the sources of variation required for selecting particular traits. Yacon FOS is an inulin-type of oligofructan mostly composed of fructans with low Degree of Polymerization (DP), from 3 to 10 fructan units (Ohyama et al. 1990; Goto et al., 1995; Paredes et al., 2018). Yacon roots have very low starch concentration and the amount of inulin, a fructan with high DP, is rather low in comparison with Jerusalem artichoke (Helianthus tuberosus) (Ohyama et al., 1990).

The tuberous yacon roots may be considered a functional food by its content in FOS, a prebiotic which confers its functional properties, mostly related to the increase of lactobacilli and bifidobateria in the gut (Miyaguchi et al., 2015), and the resulting benefits for hyperglycemic and hyperlipidemic (high cholesterol) individuals. However, it should be consumed in moderate quantities (Sabater-Molina et al., 2009; Aluko, 2012; Mentreddy et al., 2007; Ojansivu et al., 2011; Choque et al., 2013; Almeida et al., 2015; Caetano et al., 2016). Side-effects like flatulence or diarrhoea might occur in individuals with dietary fructose intolerance because of the high levels of this sugar found in some yacon extracts. Interestingly, yacon leaves also present bioactive compounds with antioxidant and antidiabetic properties (Villacrés et al., 2007; Russo et al., 2015). The consumption of FOS has been related to a delay in gastric emptying time which extends satiety feeling reducing the frequency or amount of food intake (Aluko, 2012). An additional benefit of this lower nutrient transit is the reduction in nutrient absorption rate and postprandial (= following the intake of a meal) glucose levels (Aluko, 2012). Colon fermentation of FOS by the gut microbiota leads to the production of short chain fatty acids which in turn acidifies and favours growth of beneficial lactobacilli and bifidobacteria (Jimenez et al., 2015; Sousa et al., 2015b). Further positive effects of including FOS in the diet are improvement of glucose control in hyperglycemic individuals (Ludeña et al., 2004; Scheid et al., 2014; Gomes da Silva et al.,2017), reduction in plasma cholesterol (Caetano et al., 2016) and increase in the formation of healthy colonocytes (Aluko 2012; de Almeida et al., 2014). Evidence of improvement in the immune system has been described in mice after yacon feeding (Choque Delgado et al., 2012). In children, when yacon flour was introduced in their diets, also led to an improvement in intestinal immune response but no effect in their 
nutritional status in iron and zinc (Vaz-Tostes et al., 2014), providing further support for the prebiotic activity of yacon. In experiments with rats, no toxicity was observed when feeding with up to $6.8 \mathrm{~g} \mathrm{FOS} \mathrm{kg}^{-1}$ body weight day ${ }^{-1}$ (Genta et al., 2005).

Further bioactive components in yacon roots are antioxidants found in its flesh (and flour) (Campos et al., 2012; Jiménez and Sammán, 2014; Sousa et al., 2015a). The compounds found in roots with antioxidant properties are phenols, mostly chlorogenic and caffeic acids, and in minor concentrations coumaric and protocatechuic acid (Sousa et al., 2015a). The tuberous yacon roots require a hot water treatment (blanching) to inactivate peroxidases and polyphenol oxidases for improving the quality (in terms of colour and antioxidant content) of derived flours (Campos et al., 2016). Dehydrated yacon leaves are recommended for preparation of infusions with antioxidant and antidiabetic properties (Villacrés et al., 2007; Andrade et al., 2014; Russo et al., 2015). The concentration of antioxidant phenols and flavonoids in the yacon leaves varies depending on the cultivars (red or white), the leaf age and the extraction process (Khajehei et al., 2017).

\section{Crop History}

Yacon roots have been cultivated since pre-Columbian times in the Andean region (Estrella, 1988). It is believed that the Incas brought the species to Ecuador prior to the Spanish conquest (Grau and Rea, 1997, Hermann, 1997).

\section{Traditional production and consumption}

In both Ecuador and Bolivia, its production is not found in national statistics since it is grown mainly for self-consumption. Barrera et al. (2004) indicated that yacon production has been reduced to the point that it is almost lost in the farms.

In Ecuador yacon is cultivated in several provinces of the Andes mostly in Loja, Azuay, Cañar and Bolívar (Hermann, 1997). In Ecuador yacon can produce between 30 to $70 \mathrm{t} \mathrm{ha}^{-1}$ (NRC, 1989, Grau and Rea, 1997) and 3 morphotypes have been described: purple, dark green and light green (Tapia et al., 2004). Yacon can be found associated with other indigenous crops typical of this altitude, such as melloco, mashua and oca (Barrera et al., 2004).

In Bolivia, the production of yacon takes place mainly in the inter-Andean valleys, being cultivated mainly for self-consumption in specific communities of the municipalities of Charazani, Curva, Mocomoco, Sorata, Irupana and Coroico (department of La Paz, Bolivia). The production of yacon is marginal and done annually 
or biennially according to the traditions of the producing communities in association with other crops such as maize and arracacha, but also in borders and empty spaces of family gardens (LATINCROP, 2017)

In Ecuador and Bolivia, yacon is traditionally consumed peeled fresh, after a process of "sweetening" that is sun exposure, which increases the fructose content from 2.4\% to 21\% (Estrella, 1988; Grau and Rea, 1997; Barrera et al., 2004). In some places in Ecuador it is consumed on the day of the dead (NRC, 1989). Another potential use of the species is forage; cattle can be fed with stems and leaves, which contain between 11\% and 17\% protein (Barrera et al., 2004; Hermann, 1997).

Medicinal uses

In Bolivia yacon is commonly consumed by diabetics and people suffering from digestive problems. Properties to treat kidney problems and skin-rejuvenating activity also have been mentioned. Medicinal (antidiabetic) properties have been attributed to yacon leaves (Grau and Rea, 1996; Tapia et al., 1996)

The essential oil from the leaves of yacon was isolated and twenty-one chemical constituents were identified, their amounts accounted for $96.2 \%$ of the total composition ( $\mathrm{Li}$ et al., 2009). Leaves extracts can be used in prevention and treatment of chronic diseases involving oxidative stress, particularly diabetes (Valentová et al., 2004).

\section{Ahipa (Pachyrhizus ahipa)}

Ahipa is another tuberous-root producing crop which is mostly consumed fresh as a fruit (Grau, 1997; Sorensen 1996) but also is an alternative source of gluten-free starch (Doporto et al. 2011). The crude protein content is higher (3.2\%) than in arracacha, yacon and mashua (Table 2). Ahipa roots may be peeled like a banana or eaten with a spoon. Its sugar content is high compared to yacon (28-47\%) (Table 1) mostly after exposing roots into the sun (Rodriguez et al. 2017) and composed by sucrose and glucose (E.O. Leidi, unpublished). Other nutrients such as low fat and 20-25\% dietary fiber make ahipa an adequate source of functional components in the diet with the advantage of low anti-nutrient content (Dini et al. 2013).

The starch content in ahipa roots reaches 44-65\% (Dini et al., 2013) and being a gluten-free product makes it a suitable functional food ingredient for people affected by celiac disease (Lopez et al. 2010; Doporto et al., 2011). It may be used in yoghurts with dietary fiber, for making juices and fermented beverages, and because of the sugars 
quality is recommended as food product to combat glycemia (Doporto et al. 2013; Ramos de la Peña et al. 2013;). Mineral contents in ahipa roots are similar than in arracacha, yacon and mashua (Table 1). In the city of Tarija (Southern Bolivia), is common to find fresh ahipa root juices offered in the urban markets (Rodriguez et al. 2018).

\section{Crop history}

The species was cultivated by the Incas since pre-Columbian times as well as other indigenous inhabitants of the coast of Peru (Ugent et al. 1986; Sørensen 1996). Ahipa has been represented in textiles, pottery and paintwork found in Paracas (Peru) (Yacovleff and Muelle, 1934; Towle, 1952; Ugent et al., 1986) and also in Nazca embroidered textiles (Brucher, 1977; O'Neale and Whitaker, 1947). However, nowadays ahipa in Peru is misunderstood with "ashipa" as common name of $P$. tuberosus, which is cultivated in the tropical region of Peru (Guillen and Roldan 2014). In Bolivia, ahipa was first described by Weddell (1857) after his visit to La Paz city. Scarce presence in the northern region of Argentina and southern Bolivia was reported by Campos (1888) and Parodi (1935, 1936). Later, Cardenas (1989) and Rea (2004) recorded ahipa cultivation in the inter-Andean rural communities of La Paz, Cochabamba, Chuquisaca and Tarija.

\section{Traditional production and consumption}

Ahipa is traditionally cultivated in Bolivia and was for the first time included in the last agricultural census report (INE, 2015). Nevertheless, the production at national level in Bolivia is low and small farmers are the custodians for the in-situ conservation of ahipa. In the inter-Andean valley rural communities of La Paz, Cochabamba, Chuquisaca and Tarija, farmers grow ahipa in traditional polyculture systems (Rodriguez et al. 2017). Ahipa is cultivated in the southern part in Chuquisaca and Tarija in Pilaya River communities $\left(68 \mathrm{t} \mathrm{ha}^{-1}\right)$. In contrast in other communities the production of ahipa is small below of $40 \mathrm{t} \mathrm{ha}^{-1}$ (Rodriguez et al. 2018) and combined with other traditional and cash crops, which shift ahipa cultivation in a way to be less cultivated every year.

Refreshing tuberous ahipa roots are traditionally used every year in the southern Bolivian region of Tarija in the Catholic festivity of 'Corpus Christi'. This celebration gathers urban and rural inhabitants and Ahipa is the main food product. Due to its swollen root shape, the people make a cup hollowing out the pulp with a spoon, and it is decorated with little white flowers, and filled with sweet wine or "chicha de uva". This traditional celebration symbolizes the "Blood of Jesus Christ". In rural 
households, people are used to eat ahipa pealed as a banana or cut and eat with a spoon.

\section{Medicinal uses}

Its consumption relies by the good taste of the root as an apple and on its curative values. The ahipa juice consumption is recommended to drink at midday after the lunch for treatment of digestive problems (stomach ulcers, gastritis) and kidney problems. Ahipa root slice can be included in salads, which is recommended for stomach treatment.

\section{Mashua (Tropaeolum tuberosum)}

Isaño or mashua are the common names for another Andean root crop that should be considered a functional crop containing compounds with nutraceutical properties (Grau et al., 2003; Lim, 2016). It is cultivated from Bolivia to Colombia at altitudes ranging 1500-4200 meters above sea level where it shows cold tolerance (Tapia and Fries, 2007). The tuberous mashua root is a storage organ with a high carbohydrate and sugar content (Table 1), but it also contains other compounds which confer its significant value in folk medicine and pharmaceutical research (Vig et al., 2009; Traka and Mithen, 2009; Aruquipa et al., 2017). It has a significant concentration in vitamin C, antioxidants and glucosinolates (Cadima et al., 2003; Grau et al., 2003; Campos et al., 2006; Ortega et al., 2006). Glucosinolates are degraded into isothiocyanates, compounds, which hold antifungal, antibacterial, antioxidant and anticarcinogenic activities (Vig et al., 2009). In vitro assays have confirmed the antifungal properties of $p$-methoxybenzyl glucosinolate isolated from Colombian mashuas (Martin and Higuera, 2016). The product of glucosinolate hydrolysis, isothiacyanates, have significant bioactivity as antibiotic, nematicide, and anticarcinogenic (Vig et al., 2009; Traka and Mithen, 2009). The characteristic piquant flavor of mashua is produced by p-methoxybenzyl isothiocyanate (Grau et al., 2003). This characteristic makes the mashua culture resistant to pests (Grau et al., 2003).

Its traditional use as libido reducing agent (= "anti-aphrodisiac") has been documented and called "anti-maca" (Grau et al., 2003; Schjellerup 2005; Aruquipa et al., 2016). Hence, many Andean men recommend it for women while refusing to take it themselves (National Research Council, 1989). Experiments with male rats fed with mashua showed a 45\% drop in testosterone (Fuccillo et al., 2007). Also in rats, mashua extracts led to a reduction in testicular function (lower number of spermatids 
and epididymal sperm) but no change in serum testosterone levels (Cárdenas-Valencia et al., 2008). Other recommended use is for treatment of renal, liver and skin disorders (Cadima et al., 2003). When the Incas conquered new lands, the soldiers should carry on mashua tubers so they 'would forget about their women' (Schjellerup, 2005).

The content of starch and sugars in tuberous mashua roots is high, but variable (Table 1), and probably affected by factors like genotype, growth conditions, maturity at harvest and postharvest treatment. A study of food and industrial properties of mashua starch showed it would be more easily digested than starches from oca and papalisa (Valcárcel-Yamani et al., 2013). The tuberous mashua root has a remarkable concentration of natural antioxidants like phenolic compounds (among them, anthocyanins) and carotenoids (Campos et al., 2006; Chirinos et al., 2006; Salluca et al., 2008). Phenolic compounds from mashua tuber resulted effective as as an alternative source of natural antioxidants by the oil industry (Betalleluz-Pallardel et al., 2012).

Postharvest treatment not only affects carbohydrate composition but also the content in phenolic compounds and hence, the antioxidant properties of the tuberous roots (Chirinos et al., 2007). In comparative studies with other Andean root or tuber crops (arracacha, melloco, miso, oca, yacón), mashua showed the highest concentration in vitamin C and pro-vitamin A (Espín et al., 2004).

Tuberous root yields may be very high, up to $70-80 \mathrm{t} \mathrm{ha}^{-1}$ in experimental crops in diverse agroecological conditions of Ecuador and Bolivia (Barrera et al., 2004; Gonzales et al., 2003), although normally commercial crops do not exceed 5-15 t ha ${ }^{-1}$ (Grau et al., 2003; Tapia and Fries, 2007). In the region of Puno (Peru), the mean yield for the period 2001-2010 was $6.7-7.2 \mathrm{~kg} \mathrm{ha}^{-1}$ and annual production of 6.4 metric tonnes (Dirección de Información Agraria, 2012).

Among the species presented in this review, mashua presents a relatively high iron and zinc concentration which might be useful for supplementing the intake of these nutrients considered deficient in many countries including both developed and developing ones (Cakmak et al., 2017).

\section{Crop History}

Before the Inca conquest, the Puruháes of Ecuador ate "majuas" (Estrella, 1988). In 1582 appears the first chronicle on the use of añu (isaño or mashua) in Cuenca (Ecuador) (Hodges, 1946). Natives of Alausí (Chimborazo) already planted mashuas with potatoes, corn and mellocos in 1592 (Estrella, 1988). 


\section{Traditional production and consumption}

In Bolivia and Ecuador, this crop is not found in national statistics since it is generally used for self-consumption. Grau et al. (2003) estimated an area of production in the Andes of Ecuador of around 50 ha. Yields above $70 \mathrm{t} \mathrm{ha}^{-1}$ have been experimentally recorded (Barrera et al, 2004; Grau et al.2003). The INIAP mashua collection (Ecuador) holds 78 accessions with distinctive morphological and agronomic traits (Tapia et al., 2004). The Bolivian mashua germplasm collection keeps 75 accessions that are in the characterization stage (LATINCROP, 2017).

Mashua is interplanted with potato, oca, ulluco, faba bean, quinoa, tarwi (Andean lupin), barley, broad bean, maize or squashes. In any case, mashua is seldom monocropped in plots exceeding $2000 \mathrm{~m}^{2}$ (Grau et al., 2003).

In Bolivia, the production of mashua is carried out in the highlands, in plots in high places or on the slopes of the communities, these production areas have greater slopes. It is distributed in the altiplanic regions where it is considered as a marginal crop that is planted in small quantities and for self-consumption, along with other tubers such as potatoes, oca and papalisa. The sowing is carried out from August to September and the harvest is carried out from May to June. The cycle of production of mashua is about a year, where you can also harvest from 9 months onwards depending on the planting period.

Mashua grows in adverse circumstances of irrigation, diseases and soil nutrients, it is a crop that serves as a fitosanitary barrier for potatoes. Precisely because of this and also because of its high resistance to frost, the crop is cultivated in association with potato and oca. Mashua crops are effective controllers in the incidence of an Andean beetleand it is frequent to find it in plots or furrows combined with other crops to reduce the attack of insects. In Bolivia, it is traditionally planted in rotation systems with other crops: the first year potatoes, the second year oca, papalisa and isaño; the third year faba or peas, the fourth year barley or oats for the feeding of cattle; and to close this cycle, tarwi (Lupinus mutabilis) is sown in the fifth year (LATINCROP,2017).

The widespread Andean practice of exposing tubers and roots to direct sunlight is also used for mashua (Grau et al., 2003). Mashua can be used as a component in many dishes, ranging from soups and stews to desserts. Boiling causes the isothiocyanates to hydrolyse, eliminating cyanide and improving taste (Grau et al., 
2003). Agroindustrial processes for the production of chips have been developed (Villacrés et al., 2016).

Medicinal uses

Mashua diets are reputed to have beneficial effects on liver and kidneys (Hodge, 1946; Barrera et al., 2004; Cadima, 2006) and to alleviate prostate, blennorrhagia and other sexually transmitted diseases (Cadima, 2006). Tapia et al. (1996) list several Ecuadorian accessions with collector information on medicinal uses for the treatment of tonsillitis, and postpartum conditions.

According to traditions recorded by the sixteenth century chroniclers, the Inca fed mashua to their troops 'so that they would forget their women' while on military operations (Patiño, 1964, citing Padre Bernabé Cobo; Johns et al., 1982). The chronicler Garcilaso affirms that the Indian gallants could frustrate this influence "holding a stick in the hand while eating the tubers" (Hodges, 1946), also Grau et al., (2003) reported the use of mashua by people with diabetes or for skin ailments.

\section{Other uses}

Mashua's aggressive growth makes it a very good ground cover, adequate for soil protection on the steep slopes of the Andes (Grau et al., 2003). Peasants in Ecuador feed mashua tubers to pigs, but it would be counterproductive with donkeys (Grau et al., 2003; Cadima, 2006).

\section{Concluding remarks}

There are several factors contributing to the loss of biodiversity in the species considered in the present review. Socioeconomic factors like reduced market prices, changes in food habits and consumer preferences, and difficult access to markets have led to a gradual reduction of their production (Tapia et al., 2004). It is of paramount importance to increase the number of plant species, which provide food worldwide in order to improve food security (IPGRI, 2004; Jacobsen et al., 2013). However, it is not only a matter of food security: maintaining richness of plant genetic diversity under cultivation make 'farming, social and economic systems more resilient to the effects of climate change' and is an important 'livelihood asset for the rural poor' (FAO, 2012).

Andean root and tuber crops are not only a source of functional elements in the diet but important and complementary resources of energy, protein and minerals. Although local peasants in the highlands of Bolivia, Ecuador and Peru still cultivate and consume these roots and tubers, the crops are receding because of numerous and 
complex reasons; from change in the food habits of new generations, to difficulties to reach the markets. Probably, awakening the international attention in combination with culinary promotion and developing more research on their properties as functional nutrients will preserve this rich heritage and in the long run will provide better economic incomes to the local population in the Andes.

\section{Acknowledgements}

This work was funded by the FP7 from the European Union (Latincrop, FP7/20072013/ under grant agreement $\left.n^{\circ} 613692\right)$.

\section{References}

Albano KM, Franco CML, Telis VRN (2014) Rheological behaviour of Peruvian carrot starch gels as affected by temperature and concentration. Food Hydrocoll. 40: 30-43.

Almeida Paula HA, Viana Abranches M, Luces Fortes Ferreira CL (2015) Yacon (Smallanthus sonchifolius): a food with multiple functions. Crit. Rev. Food Sci. Nutr. 55: 32-40.

Andrade EF, Souza Leone R, Ellendersen LN, Masson ML (2014) Phenolic profile and antioxidant activity of extracts of leaves and flowers of yacon (Smallanthus sonchifolius). Ind. Crops Prod. 62: 499-506.

Aruquipa R, Trigo R, Bosque H, Mercado G, Condori J (2016) El isaño (Tropaeolum tuberosum) un cultivo de consumo y medicina tradicional en Huatacana para el beneficio de la población boliviana. Rev. Invest. Innov. Agropec. Rec. Nat. 3: 35-40.

Betalleluz-Pallardel I, Chirinos R, Rogez H, Pedreschi R and Campos D (2012) Phenolic compounds from Andean mashua (Tropaeolum tuberosum) tubers display protection against soybean oil oxidation. Food Sci. Technol. Int. 18: 271-280.

Huaycho H, Aruquipa R, Mercado G, Trigo R, Bosque H, Condori (2016) Conocimientos tradicionales en yacón o aricoma (Smallanthus sonchifolius) en comunidades de Mocomoco, Coroico e Irupana de La Paz. Rev. Invest. Innov. Agropec. Rec. Nat. 3: 41-53.

Barrera V, Tapia C, Monteros A (eds) (2004) Raíces y tubérculos andinos: Alternativas para la conservación y uso sostenible en el Ecuador. INIAP-CIP-Agencia Suiza Desarr. Coop., Quito, Ecuador; Lima, Perú.

Barrera V, Espinosa P, Tapia C, Monteros A, Valverde F (2004) Caracterización de las raíces y los tubérculos andinos en la ecoregión Andina del Ecuador. In: Raíces y tubérculos andinos: Alternativas para la conservación y uso sostenible en el Ecuador (Barrera V, Tapia C, Monteros A, eds.), pp. 3-30. INIAP-CIP-Agencia Suiza Desarr. Coop., Quito, Ecuador; Lima, Perú.

Bazile D, Jacobsen SE, Verniau A (2016) The Global Expansion of Quinoa: Trends and Limits. Front Plant Sci. 7: 622. doi: 10.3389/fpls.2016.00622 
Bosque H, Trigo R, Mercado G, Rojas V, Cestari M, Montes de Oca M, Delgadillo C (2016) Revalorización sostenible de la agrobiodiversidad a través de la gastronomía: La visión del proyecto LATINCROP. Rev. Invest. Innov. Agropec. Rec. Nat. 3: 99-102.

Brücher H (1977) Tropische Nutzpflanzen: Ursprung, evolution und domestikation. Springer-Verlag, Berlin Heidelberg, doi.org/10.1007/978-3-662-13237-1

Cadima X, García W, Patiño F (2003) El isaño (Tropaeolum tuberosum R\&P): Avances en la investigación de un cultivo subutilizado. Documento de trabajo No. 24, Fundación PROINPA, Cochabamba, Bolivia.

Cadima X (2006) Tubérculos. In: Botánica Económica de los Andes Centrales ( Moraes M, Øllgaard RB, Kvist LP, Borchsenius F, Balslev H, Eds.) pp. 347-369. Universidad Mayor de San Andrés, La Paz.

Caetano BFR, Moura NA de, Almeida APS, Dias MC, Sivieri K, Barbisan LF (2016) Yacon (Smallanthus sonchifolius) as a food supplement: Health-promoting benefits of fructooligosaccharides. Nutrients 8: 436 doi:10.3390/nu8070436

Cakmak I, McLaughlin MJ, White P (2017) Zinc for better crop production and human health. Plant Soil 411: 1-4.

Campos D (1988) De Tarija a la Asunción. Expedición Boliviana de 1883; Informe del Doctor Daniel Campos, Comisario Nacional y Delegado del Supremo Gobierno.

Buenos Aires, Argentina, pp. 184-185. Accessed on 5 May 2018, online: https://archive.org/details/detarijaalaasun00quijgoog (in Spanish)

Campos D, Aguilar-Gálvez A, Pedreschi R (2016) Stability of fructoligo saccharides, sugars and colour of yacon (Smallanthus sonchifolius) roots during blanching and drying. Int. J. Food Sci. Technol. 51: 1177-1185.

Campos D, Betalleluz-Pallardel I, Chirinos R, Aguilar-Gálvez A, Noratto G, Pedreschi R (2012) Prebiotic effects of yacon (Smallanthus sonchifolius Poepp.\& Endl), a source of fructoligosaccharides and phenolic compounds with antioxidant activity. Food Chem. 135: 1592-1599.

Campos D, Noratto G, Chirinos R, Arbizu C, Roca W, Cisneros-Zevallos L (2006) Antioxidant capacity and secondary metabolites in four species of Andean tuber crops: native potato (Solanum sp.), mashua (Tropaeolum tuberosum Ruiz \& Pavón), Oca (Oxalis tuberosa Molina) and ulluco (Ullucus tuberosus Caldas). J. Sci. Food Agric. 86: 1481-1488.

Cardenas M (1989) Manual de plantas económicas de Bolivia. 2nd edn. Los Amigos del Libro, Cochabamba, Bolivia (in Spanish).

Cárdenas-Valencia I, Nieto J, Gasco M, Gonzales C, Rubio J, Portella J, Gonzales GF (2008) Tropaeolum tuberosum (mashua) reduces testicular function: effect of different treatment times. Andrologia 40: 352-357.

Chávarry RC (2007) Influencia de las condiciones de almacenaje del yacón fresco (Smallanthus sonchifolius Poepp. \& Endl.) en sus compuestos bioactivos. Tesis. In: Base de datos. Yacón (Smallanthus sonchifolius (Poepp.) H. Rob., 1st edition. Peru Biodiverso, Lima 2009. 
Chirinos R, Campos D, Arbizo C, Rogez H, Rees JF, Larondelle Y, Noratto G, Cisneros-Zevallos (2007) Effect of genotype, maturity stage and post-harvest storage on phenolic compounds, carotenoid content and antioxidant capacity, of Andean mashua tubers (Tropaeolum tuberosum Ruiz \&Pavón). J. Sci. Food Agric. 87: 437-446.

Chirinos R, Campos D, Warnier M, Pedreschi R, Rees JF, Larondelle Y (2008) Antioxidant properties of mashua (Tropaeolum tuberosum) phenolic extracts against oxidative damage using biological in vitro assays. Food Chem. 111: 98-105.

Chirinos R, Rogez H, Campos D, Pedreschi R, Larondelle $Y$ (2007) Optimization of extraction conditions of antioxidant phenolic compounds from mashua (Tropaeolum tuberosum Ruíz\&Pavón) tubers. Sep. Pur. Technol. 55: 217-225.

Choque Delgado GT, Cunha Tamashiro WMS, Maróstica Jr MR, Pastore GM (2013) Yacon (Smallanthus sonchifolius): A functional food. Plant Foods Hum. Nutr. 68: 222228.

Choque Delgado GT, Thomé R, Gabriel DL, Tamashiro WMSC, Pastore GM (2012) Yacon (Smallanthus sonchifolius)-derived fructoligosaccharides improve immune parameters in the mouse. Nutr. Res. 32: 884-892.

Coll Aráoz MV, Kortsarz González AM, Mercado MI, Ponessa GI, Grau A, Catalán CAN (2014) Ontogeny and total sugar content of yacon tuberous roots and other three Smallanthus species (Heliantheae, Asteraceae), insights on the development of a semi-domesticated crop. Genet. Resour. Crop Evol. 61: 163-172.

Dirección de Información Agraria (2012) Tubérculos y raíces. Boletín de Información Estadística Agraria, Puno, Ministerio de Agricultura, Peru.

Di Bartolomeo F, Van den Ende W (2015) Fructose and fructans. Opposite effects on health? Plant Foods Hum. Nutr. 70: 227-237.

Doporto MC, Mugridge A, García MA, \& Viña SZ (2011) Pachyrhizus ahipa (Wedd.) Parodi roots and flour: Biochemical and functional characteristics. Food Chem. 126: 1670-1678.

Doporto MC, Dini C, Vina SZ, Garcia MA (2013) Pachyrhizus ahipa roots and starches: composition and functional properties related to their food uses. Stärke 66: 539-548.

Douglas JA, Douglas MH, Deo B, Follett JM, Scheffe, JJC, Sims IM, Welch RAS (2005a) Research and development of yacon (Smallanthus sonchifolius) production in New Zealand. Acta Hortic. 670: 79-85.

Douglas JA, Follett JM, Waller JE (2005b) Effect of propagule weight on production of yacon (Smallanthus sonchifolius). New Zealand J Crop Hort. Sci. 33: 143-148.

Dwivedi S, Sahrawat K, Puppala N, Ortiz R (2014) Plant prebiotics and human health: Biotechnology to breed prebiotic-rich nutritious food crops. Elect. J. Biotechnol. 17: 238-245.

Espín S, Villacrés E, Brito B (2004) Caracterización físico-química, nutricional y funcional de raíces y tubérculos andinos. In: Raíces y tubérculos andinos: Alternativas para la conservación y uso sostenible en el Ecuador (Barrera VH, Tapia CG, Monteros AR, eds.) pp. 91-116. INIAP-CIP, Ecuador. 
Espinosa P, Vaca R, Abad J, Crissman Ch (1996) Raíces y tubérculos andinos, cultivos marginados en el Ecuador. Situación actual y limitaciones para la producción. Centro Internacional de la Papa. Departamento de Ciencias Sociales. Quito, Ecuador. Ediciones Abya Yala. 178 p.

Espinosa P (2004) Consumo, aceptabilidad y oportunidad de aumentar la demanda urbana de las RTAs. In: Raíces y tubérculos andinos: Alternativas para la conservación y uso sostenible en el Ecuador (Barrera VH, Tapia CG, Monteros AR, eds.) pp. 155176. INIAP-CIP, Ecuador.

Estrella E (1988) El Pan de América. Etnohistoria de los alimentos aborígenes en el Ecuador. Centro de Estudios Históricos. Madrid. 415 p. http://repositorio.educacionsuperior.gob.ec/handle/28000/884

FAO (2012) http://www.fao.org/fileadmin/templates/food_composition/documents/Cordoba_NUS_Declaration_2012_FINAL.pdf

FAO/INFOODS (2013) Food Composition Database for Biodiversity Version 2.1 BioFoodComp2.1. FAO, Rome.

FAO (2013) Traditional high Andean cuisine: Allin Mikuy/Sumak Mikuy. ISBN 978-92-5106524-2.

Fernández EC, Viehmannová I, Lachman J, Milella L (2006) Yacon [Smallanthus sonchifolius (Poepp. \& Endlicher) H. Robinson]: a new crop in the Central Europe. Plant Soil Environ. 52: 564-570.

Flores D (2010) Uso histórico: Yacón Smallanthus sonchifolius (Poepp.) H. Rob. Base Datos Peru Biodiverso, Proyecto Biocomercioperu.

Fuccillo D, Sears L, Stapleton P (2007) Biodiversity in Trust: Conservation and Use of Plant Genetic Resources in CGIAR Centres. Cambridge University Press, 388 pp.

Fukai K, Ohno S, Goto K, Nanjo F, Hara Y (1997) Seasonal fluctuations in fructan content and related enzyme activities in yacon (Polymnia sonchifolia). Soil Sci. Plant Nutr. 43: 171-177.

Gahukar RT (2014) Potential of minor food crops and wild plants for nutritional security in the developing world. J Agric. Food Inform. 15: 342-352.

García A, Pacheco Delahaye E (2008) Characterization of postharvest arracacha grown in the Municipality Tovar, Merida State, Venezuela. Agron. Trop. 58: 409-416.

García A, Pacheco Delahaye E (2010) Evaluación de una bebida instantánea a base de harina de arracacha (Arracacia xanthorrhiza) con la adición de ácido fólico. Rev. Chil. Nutr 37: 480-492.

García MR, Gómez-Sánchez Prieto I, Espinoza Barrientos C, Bravo Rebatta F, Ganoza Morón L (2009) Tablas peruanas de composición de alimentos, 8aa ed. INS, Ministerio de Salud, Lima. ISBN 978-9972-857-73-7.

Genta SB, Cabrera WM, Grau A, Sanchez SS (2005) Subchronic 4-month oral toxicity study of dried Smallanthus sonchifolius (yacon) roots as a diet supplement in rats. Food Chem. Toxicol. 43: 1657-1665. 
Gomes da Silva MF, Dionísio AP, Ferreira Carioca AA, Silveira Adriano L, Oliveira Pinto C, Pinto de Abreu FA, Wurlitzer NJ, Araújo IM, dos Santos Garruti D, Ferreira Pontes D (2017) Yacon syrup: Food applications and impact on satiety in healthy volunteers. Food Res. Int. 100: 460-467.

Gonzales S, Almanza J, Oros R, Devaux A (2003) Producción de oca (Oxalis tuberosa), papalisa (Ullucus tuberosus) e isaño (Tropaeolum tuberosum): Avances en la investigación del manejo agronómico. Fundación PROINPA, Cochabamba, Bolivia.

Goto K, Fukai K, Hikida J, Nanjo F, Hara Y (1995) Isolation and structural analysis of oligosaccharides from yacon (Polymnia sonchifolia). Biosci. Biotech. Biochem. 59: 2346-2347.

Grau A, Ortega Dueñas R, Nieto Cabrera C, Hermann M (2003) Mashua (Tropaeolum tuberosus Ruíz \& Pav. Promoting the conservation and use of underutilized and neglected crops. 25. International Potato Center, Lima, Peru/International Plant Genetic Resources Institute, Rome, Italy.

Grau A (1997) Ahipa, la legumbre tuberosa de los Andes. Ciencia Hoy 7: 31-38.

Grau A, Rea J (1997) Yacon (Smallanthus sonchifolius (Poepp. \&Endl.) H. Robinson. In: Andean Roots and Tubers: ahipa, arracacha, maca and yacon. (Hermann M, Heller, eds.) pp. 199-242. IPGRI, Rome.

Guillen W, Roldan A (2014) Ficha Tecnica de Ashipa (Pachyrhizus tuberosus). Ministerio de Agricultura y Riego (MINAGRI), Instituto Nacional de Innovacion Agraria (INIA), Lima, Peru, 8p.

Heredia Zárate NA, Vieira MC, Rech J, Quast A, Pontim BCA, Gassi RP (2008) Yield and gross income of arracacha in monocrop and intercropping with the Japanese bunching onion and parsley. Hort Bras 26:287-291.

Hermann M (1997) Arracacha (Arracacia xanthorrhiza Bancroft). In: Andean Roots and Tubers: ahipa, arracacha, maca and yacon. (Hermann M, Heller, eds.) pp. 75-172. IPGRI, Rome.

Hermann M, Freire I, Pazos C (1999) Compositional diversity of the yacon storage root. Andean Root and Tubers, CIP Program Report 1997-98, pp. 425-432.

Hodge W.H. (1954) The edible arracacha, a little-known root crop of the Andes. Econ Bot 8: 195-221.

Huaycho H, Aruquipa R, Mercado G, Trigo R, Bosque H, Condori J (2016) Conocimientos tradicionales en yacón o aricoma (Smallanthus sonchifolius) en comunidades de Mocomoco, Coroico e Irupana de La Paz. Rev. Invest. Innov. Agropec. Rec. Nat. 3: 41-53.

INE (2015) Censo Agropecuario 2013 Bolivia. Instituto Nacional de Estadistica, La Paz, Bolivia.

INEC (2007). Situación del micro-productor agropecuario. Ecuador. 2007. Instituto Nacional de Estadísticas y Censos. 23 p.

Inga Guevara M, Betalleluz Pallardel I, Kina Noborikawa M, Campos Gutiérrez D (2015) Optimización del proceso de extracción de los fructooligosacáridos de yacón 
(Smallantus sonchifolius). Rev. Soc. Quim. Perú 81: 263-272.

Jacobsen SE, Sorensen M, Pedersen SM, Weiner J (2013) Feeding the world: genetically modified crops versus agricultural biodiversity. Agron. Sustain. Dev. 33: 651-662.

Jacobsen, S-E, Sørensen M, Pedersen SM, Weiner J (2015) Using our agrobiodiversity: plant-based solutions to feed the world. Agron. Sustain. Dev. $35: 1217-1235$.

Jaimez RE, Santos N, Añez B, Vásquez J, Espinoza W (2008) Photosynthesis of fieldgrown arracacha (Arracacia xanthorrhiza Bancroft) cultivars in relation to root-yield. Sci. Hort. 118: 100-105.

Jiménez ME, Sammán N (2014) Caracterización química y cuantificación de fructooligosacáridos, compuestos fenólicos y actividad antirradical de tubérculos y raíces andinos cultivados en el noroeste de Argentina. Arch. Latinoam. Nutr. 64: 131138.

Jiménez ME, Rossi A, Samman N (2015) Health properties of oca (Oxalis tuberosa) and yacon (Smallanthus sonchifolius). Food Funct. 6: 2166. DOI: 10.1039/c5fo00174a

Johns T, Kitts W, Newsome F, Towers GH (1982) Anti reproductive and other medicinal effects of Tropaeolum tuberosum. J. Ethnopharmacol. 5: 149-161.

Khajehei F, Niakousari M, Damyeh MS, Merkt N, Claupein W, Graeff-Hoenninger S (2017) Impact of ohmic-assisted decoction on bioactive components extracted from yacon (Smallanthus sonchifolius Poepp.) Leaves: Comparison with conventional decoction. Molecules 22: 2043; doi:10.3390/molecules22122043

Kim SJ, Jin YI, Nam JH, Hong SY, Sohn WB, Kwon OK, Chang DC, Cho HM, Jeong JC (2013) Comparison of nutrient composition of yacon germplasm. Korean J. Plant Res. 26(1): 9-18. [kor]; DOI: 10.7732/kjpr.2013.26.1.009

Lachman J, Havrland B, Fernández EC, Dudjak J (2004) Saccharides of yacon [Smallanthus sonchifolius (Poepp. et Endl.) H. Robinson] tubers and rhizomes and factors affecting their content. Plant Soil Environ. 50: 383-390.

LATINCROP (2017). Estado de la conservación de raíces y tubérculos subutilizados en el departamento de La Paz: Racacha, yacón e isaño. La Paz: IIAREN, Facultad de Agronomia - UMSA.

Li J, Liu J, Lan H, Zheng M, Rong T (2009) GC-MS analysis of the chemical constituents of the essential oil from the leaves of yacon (Smallanthus sonchifolia). Front. Agric. China 3: 40-42.

Lim TK (2015). Arracacia xanthorrhiza. In: Edible Medicinal and Non-Medicinal Plants, Vol. 9. Springer, Dordrecht. DOI 10.1007/978-94-017-9511-1_7.

López OV, Viña SZ, Pachas ANA, Sisterna MN, Rohatsch PH, Mugridge A, Fassola HE, Garcia MA (2010) Composition and food properties of Pachyrhizus ahipa roots and starch. Int. J. Food Sci. Technol. 45: 223-233.

Martín JC, Higuera BL (2016) Glucosinolate composition of Colombian accessions of mashua (Tropaeolum tuberosum Ruíz \& Pavón), structural elucidation of the 
predominant glucosinolate and assessment of its antifungal activity. J. Sci. Food Agric. 96: 4702-4712.

Mazón N (1993) Análisis de la variación morfológica e isoenzimática de la colección ecuatoriana de zanahoria blanca (Arracacia xanthorrhiza Bancroft). Tesis Ing. Agrónomo. Escuela Superior Politécnica de Chimborazo. Riobamba, Ecuador. 135 p.

Mazón N, Castillo R, Hermann M, Espinosa P (1996) La arracacha o zanahoria blanca (Arracacia xanthorrhiza Bancroft). Publicación Miscelánea No. 67.

Melting Pot Bolivia (2017) Latincrop: Revalorización de productos nativos subutilizados [Digital book] www.gustubo.restaurantgustu.com/librolatincrop

Mentreddy SR (2007) Medicinal plant species with potential antidiabetic properties. J. Sci. Food Agric. 87: 743-750.

Miyaguchi Y, Tomatsuri T, Toyoda A, Inoue E, Ogawa Y (2015) Effect of yacon tuber (Smallanthus sonchifolius)-derived fructooligosaccharides on the intestinal flora and immune system of OVA-sensitized BALB/c mice. Food Sci. Technol. Res. 21:255-262.

Monge A (2008) Functional foods. Reflections of a scientist regarding a market in expansion. Rev. Soc. Quim. Perú 74: 138-147.

National Research Council (1989) Lost crops of the Incas: Little known plants of the Andes with promise for worldwide cultivation. National Academy Press, Washington DC.

Ohyama T, Ito O, Yasuyoshi S, Ikarashi T, Minamisawa K, kubota m, Tsukihashi t, Asami t (1990). Composition of storage carbohydrate in tubers of yacon (Polymnia sonchifolia). Soil Sci. Plant Nutr. 36: 167-171.

Ojansivu I, Ferreira CL, Salminen S (2011) Yacon, a new source of prebiotic oligosaccharides with a history of safe use. Trends Food Sci. Technol. 22: 40-46.

O'Neal LM, Whitaker TW (1947) Embroideries of the Early Nazca Period and the Crop Plants Depicted on Them. Southwestern J. Anthropol. 3: 294-321.

Ortega O, Kliebenstein D, Arbizu C, Ortega R, Quiros C (2006) Glucosinolate survey of cultivated and feral mashua (Tropaeolum tuberosum Ruiz \& Pavon) in the Cuzco region of Peru. Econ. Bot. 60: 254-264.

Padulosi S, Amaya K, Jäger M, Gotor E, Rojas W, Valdivia R (2014) A holistic approach to enhance the use of neglected and underutilized species: The case of Andean grains in Bolivia and Peru. Sustainability 6: 1283-1312.

Paredes LLR, Smiderle FR, Santana-Filho AP, Kimura A, lacomini M, Sassaki GL (2018) Yacon fructans (Smallanthus sonchifolius) extraction, characterization and activation of macrophages to phagocyte yeast cells. Int. J. Biol. Macromol. 108:10741081.

Parodi LR (1935) Relaciones de la agricultura prehispánica con la agricultura argentina actual: observaciones generales sobre la domesticación de las plantas. Anales Acad. Nac. Agr. Vet. Buenos Aires 1:115-167 (in Spanish)

Parodi LR (1936) Contribution à l'étude des plantes alimentaires indigènes cultivées en 
Argentine. Rev. Int.Bot. Appl. Agric. Trop. 16:177-189 (in French)

Pedreschi R, Betalleluz-Pallardel I, Chirinos R, Curotto C, Campos D (2011) Impact of cooking and drying on the phenolic, carotenoid contents and in vitro antioxidant capacity of Andean Arracacha (Arracacia xanthorrhiza Bancr.) root. Food Sci. Technol. Int. 17: 319-330.

Ramos Zapana R, Arias Arroyo G (2010) Evaluación químico bromatológica de las variedades Yurac Llajum, Qello Llajum y Yurac Checche de Smallanthus sonchifolius (Poepp \& Endl) H. Robinson (yacón) procedente de Puno. Ciencia Invest. 13: 72-76.

Ramos-de-la-Peña AM, Renard CMGC, Wicker L, Contreras-Esquivel JC (2013) Advances and perspectives of Pachyrhizus spp. in food science and biotechnology. Trends Food Sci. Technol. 29: 44-54.

Rea J (2004) Conservación y manejo in situ de recursos fitogenéticos agrícolas en Bolivia. In: Seminario J (ed) Capítulo 3: Raíces Andinas: Contribuciones al conocimiento y a la capacitación. Serie: Conservación y uso de la biodiversidad de raíces y tubérculos andinos: Una década de investigación para el desarrollo (19932003) No. 6. Universidad Nacional de Cajamarca, Centro Internacional de la Papa, Agencia Suiza para el Desarrollo y la Cooperacio'n, Lima, Perú, pp 49-64 (in Spanish)

Reyes García M, Gómez-Sánchez-Prieto I, Espinosa Barrientos C, Bravo Rebatta F, Ganoza Morón L (2009) Tablas Peruanas de Composición de Alimentos (8a . Ed.), INS, Ministerio de Salud, Lima.

Rodriguez JP, Ørting B, Andreasen C, Jacobsen S-E, Sørensen M (2018) Trends and drivers of on-farm conservation of the root legume ahipa (Pachyrhizus ahipa) in Bolivia over the period 1994/96-2012. Genetic Res Crop Evol. 65: 449-469.

Rodriguez JP, Delgado I, Del Castillo C (2017) Valorización y conservación de la agrobiodiversidad en los valles inter-andinos de Bolivia. Leisa-Rev. Agroecol. 33: 3032.

Russo D, Valentao P, Andrade PB, Fernandez EC, Milella L (2015) Evaluation of antioxidant, antidiabetic and anticholinesterase activities of Smallanthus sonchifolius landraces and correlation with their phytochemical profiles. Int. J. Mol. Sci. 16: 1769617718.

Sabater-Molina M, Larqué E, Torrella F, Zamora S (2009) Dietary fructooligosaccharides and potential benefits on health (minireview). J. Physiol. Biochem. 65: 315-328.

Salluca TG, Peñarrieta M, Alvarado JA, Bergenståhlc B (2008) Determination of total phenolic compounds content and the antioxidant capacity of Andean tubers and roots (isaño, oca, ulluco, and arracacha). Rev. Boliv. Quím. 25: 58-61.

Santacruz S, Koch K, Svensson E, Ruales J, Eliasson AC (2003) Three under-utilised sources of starch from the Andean region in Ecuador. Part I. Physico-chemical characterisation. Carb. Pol. 49: 63-70.

Santacruz S, Ruales J, Eliasson AC (2003) Three under-utilised sources of starch from the Andean region in Ecuador. Part II. Rheological characterisation. Carb. Pol. 51: 8592. 
Scheid MMA, Genaro PS, Moreno YMF, Pastore GM (2014) Freeze-dried powdered yacon: effects of FOS on serum glucose, lipids and intestinal transit in the elderly. Eur. J. Nutr. 53: 1457-1464.

Schjellerup IR (2005) Incas y españoles en la conquista de los Chachapoya. Nueva edición [en línea]. Lima: Institut français d'études andines, 2005 (generado el 15 mayo 2018). Disponible en Internet: <http://books.openedition.org/ifea/4903>. ISBN: 9782821845510. DOI: 10.4000/books.ifea.4903.

Seminario J, Valderrama M, Manrique I (2003) El yacón: fundamentos para el aprovechamiento de un recurso promisorio. CIP-Univ. Nac. Cajamarca- COSUDE, Lima.

Sousa S, Pinto J, Rodriguez C, Gião M, Pereira C, Tavaria F, Malcata FX, Gomes A, Pacheco MTB, Pintado M (2015a) Antioxidant properties of sterilized yacon (Smallanthus sonchifolius) tuber flour. Food Chem. 188: 504-509.

Sousa S, Pinto J, Rodriguez C, Pereira C, Malcata FX, Pacheco MTB, Gomes AM, Pintado M (2015b) In vitro evaluation of yacon (Smallanthus sonchifolius) tuber flour prebiotic potential. Food Bioprod. Process. 95:96-105.

Sørensen M (1996) Yam bean (Pachyrhizus DC.). Promoting the conservation and use of underutilized and neglected crops, vol 2. International Plant Genetic Resources

Institute (IPGRI), Rome, p 143. http://www. bioversityinternational.org/uploads/ tx_news/Yam_bean_Pachyrhizus_DC._311.pdf

Tapia, C., R. Castillo and N. Mazón (1996) Catálogo de recursos genéticos de raíces y tubérculos andinos en Ecuador. INIAP, DENAREF, Ecuador.

Tapia C, Estrella J, Monteros A, Valverde F, Nieto M, Córdova J (2004) Manejo y conservación de RTAs in situ en fincas de agricultores y ex situ en el Banco de Germoplasma de INIAP. In: Raíces y tubérculos andinos: Alternativas para la conservación y uso sostenible en el Ecuador (Barrera V, Tapia C, Monteros A, eds.) pp. 31-74. INIAP-CIP-Agencia Suiza Desarrollo y Cooperación, Quito, Ecuador; Lima, Perú.

Tapia ME, Fries AM (2007) Guía de campo de los cultivos andinos. FAO, Roma. ISBN 978-92-5-305682-8

Tokita N, Ichikawa M, Kainuma K, Kitazawa T, Shimamura H, Narai-Kanayama A, Sato S, Kurita T, Yoshimura I, Tokita T, Iwasaki E, Iwasaki T (2015) Effects of planting density and fertilizer type on growth and yield of yacon (Smallanthus sonchifolius) tubers. Asian J. Plant Sci. Res. 5: 38-41.

Towle M (1952) Plant remains from a Peruvian mummy bundle. Botanical Museum Leaflets, Harvard University, 15(9), 223-246.

Traka M, Mithen R (2009) Glucosinolates, isothiocyanates and human health. Pytochem. Rev. 8: 269-282.

Ugent D, Pozorski S, Pozorski T (1986) Archaeological manioc (Manihot) from Coastal Peru. Econ. Bot. 40: 78-102.

Valcárcel-Yamani B, Rondán-Sanabria GG, Finardi-Filho F (2013) The physical, chemical and functional characterization of starches from Andean tubers: Oca (Oxalis tuberosa Molina), olluco (Ullucus tuberosus Caldas) and mashua (Tropaeolum tuberosum Ruiz \& Pavón). Braz. J. Pharm. Sci. 49: 453-464. 
Valentová K, Moncion A, de Waziers I, Ulrichová J (2004) The effect of Smallanthus sonchifolius on leaf extracts on rat hepatic metabolism. Cell Biol. Toxicol. 20: 109-120.

Vaz-Tostes MG, Lomar Viana M, Grancieri M, Santos Luz TC, Paula H, Pedrosa RG, Brunoro Costa NM (2014) Yacon effects in immune response and nutritional status of iron and zinc in preschool children. Nutrition 30: 666-672.

Villacrés E, Ruiz FM (2002) Raíces y tubérculos andinos: Alimentos de ayer para la gente de hoy. INIAP, Publ. Misc. № 114, Quito, Ecuador.

Villacrés E, Rubio A, Cuadrado L, Marcial N, Iñiguez D (2007) Jicama. Raíz andina con propiedades nutraceuticas. Boletín Técnico 128, INIAP, Quito, Ecuador.

Villacrés, E.; Quelal, M; Álvarez, J. 2016. Redescubriendo la oca y la mashua. Desarrollo de nuevos snacks. Editorial Académica Española. 54p.

Vig AP, Rampal G, Thind TS, Arora S (2009) Bio-protective effects of glucosinolates. A review. LWT Food Sci. Technol. 42: 1561-1572.

Weddell HA (1857) Notice sur l'Ahipa et l'Aricoma, Plantes Alimentaires du HautPérou. Ann. Sci. Nat. 4:111-115

Weir GH, Bonavia D (1985) Coprolitos y dieta del precerámico tardío de la costa peruana. Bull. Inst. Français Étud. And. $14: 85-140$.

Yacovleff E (1933) La jiquima, raíz comestible extinguida en el Peru. Rev Museo Nacional, Lima, Peru, 2: 51-66.

Yacovleff E, Muelle JC (1934) Un fardo funerario de Paracas. Rev. Museo Nacional, Lima, Peru 3: 63-153. 
Table 1. Nutritional analysis of Andean roots and tubers (\%, dry matter basis).

Significant variation might be attributed to genetic diversity but differences in sample treatment (e.g. analysis on peeled or whole storage organs) are also sources of variation in contents.

\begin{tabular}{lrrrr}
\hline & Arracacha & Yacon & Ahipa & Mashua \\
\hline Dry matter & $9-24$ & $9-14$ & $15-21$ & $7-20$ \\
Protein & 0.7 & 2.8 & 3.2 & 1.5 \\
Lipid & $0.3-0.5$ & $0.3-0.6$ & $0.4-0.6$ & $0.7-0.9$ \\
Starch & $49-86$ & $0.4-2$ & $35-54$ & $20-80$ \\
FOS* & 0 & $38-64$ & 0 & 0 \\
Sugar & $4-15$ & $11-29$ & $28-47$ & $7-55$ \\
Fiber & $1.1-4.7$ & $3.9-4.2$ & $4.4-25.9$ & $0.9-6.9$ \\
Ash & 1.0 & 2.8 & 3.8 & 0.6 \\
\hline
\end{tabular}

*, FOS: fructooligosaccharides

Sources: Reyes García et al. 2009; Hermann, 1997; Ramos Zapana and Arias Arroyo 2010; Hermann et al. 1999; Espín et al. 2004; Dini et al. 2013, Campos et al., 2012; FAO Infoods 2013; Inga Guevara et al., 2015. 
Table 2. Mineral contents in Andean roots and tubers collected from diverse locations in Bolivia and Peru (for each species, averages made across varieties and locations available for analysis. arracacha, $n=3$; mashua, $n=11$; yacon, $n=7$ : ahipa, $n=10$ ).

\begin{tabular}{lrrrr}
\hline & Arracacha & Yacon & Ahipa $^{*}$ & Mashua \\
\hline $\mathrm{N}(\%)$ & $0.45 \pm 0.01$ & $0.36 \pm 0.07$ & $0.32 \pm 0.08$ & $1.45 \pm 0.11$ \\
$\mathrm{P}(\%)$ & $0.25 \pm 0.06$ & $0.22 \pm 0.01$ & $0.14 \pm 0.03$ & $0.27 \pm 0.03$ \\
$\mathrm{~S}(\%)$ & $0.08 \pm 0.002$ & $0.05 \pm 0.01$ & $0.00 \pm 0.00$ & $0.41 \pm 0.03$ \\
$\mathrm{~K}(\%)$ & $1.35 \pm 0.17$ & $1.51 \pm 0.17$ & $1.07 \pm 0.15$ & $1.51 \pm 0.08$ \\
$\mathrm{Ca}(\%)$ & $0.06 \pm 0.01$ & $0.13 \pm 0.01$ & $0.13 \pm 0.04$ & $0.09 \pm 0.02$ \\
$\mathrm{Mg}(\%)$ & $0.05 \pm 0.002$ & $0.07 \pm 0.009$ & $0.08 \pm 0.03$ & $0.14 \pm 0.005$ \\
$\mathrm{Fe}(\mathrm{ppm})$ & $14.9 \pm 1.9$ & $20.4 \pm 3.2$ & $8.0 \pm 2.49$ & $53.7 \pm 8.4$ \\
$\mathrm{Zn}(\mathrm{ppm})$ & $6.7 \pm 1.1$ & $12.3 \pm 1.1$ & $16.7 \pm 5.14$ & $28.5 \pm 2.1$ \\
$\mathrm{Mn}(\mathrm{ppm})$ & $2.8 \pm 0.6$ & $10.8 \pm 1.2$ & $1.6 \pm 0.66$ & $13.1 \pm 1.3$ \\
$\mathrm{Cu}(\mathrm{ppm})$ & $2.3 \pm 0.1$ & $5.7 \pm 0.3$ & $8.5 \pm 3.11$ & $4.8 \pm 0.4$ \\
\hline
\end{tabular}


Table 3. Summary of beneficial properties and common uses of arracacha, yacon, ahipa and mashua according to popular and present knowledge in the countries of origin.

\begin{tabular}{|l|l|l|}
\hline & \multicolumn{1}{|c|}{} & \\
\hline Arracacha & $\begin{array}{l}\text { Easily digested starch, appropriate for babies, elderly and } \\
\text { reconvalescents. It may enrich flavour and nutritional properties } \\
\text { (vitamin A) for preparing purees, drinks, cookies and cakes. }\end{array}$ & $\begin{array}{l}\text { Villacrés and Ruiz } \\
\text { 2002; Nestle, 2010; } \\
\text { FAO, 2013; } \\
\text { MeltingPot, 2017 }\end{array}$ \\
\hline Yacon & $\begin{array}{l}\text { Source of dietary fibre (fructooligosaccharides), antioxidants and } \\
\text { sweeteners with favourable properties to individuals suffering } \\
\text { hyperglycemic or hyperlipidemic disorders. Used for the } \\
\text { preparation of chips, juices, syrups and desserts. }\end{array}$ & $\begin{array}{l}\text { Scheid et al., 2014; } \\
\text { Villacrés et al., 2007; } \\
\text { MeltingPot, 2017 }\end{array}$ \\
\hline Ahipa & $\begin{array}{l}\text { Source of high quality starch gluten-free for flours, sucrose, } \\
\text { magnesium and iron, it can be used as an alternative food } \\
\text { component to combat glycemia. Ahipa root juice is consumed } \\
\text { directly or the root pealed like banana and eaten. }\end{array}$ & $\begin{array}{l}\text { Lopez et al., 2010; } \\
\text { Dini et al., 2011; } \\
\text { Doporto et al., 2013; }\end{array}$ \\
\hline Mashua & $\begin{array}{l}\text { Traditionally considered antibiotic and antinflammatory, probably } \\
\text { due to its high content in glucosinolates, used for treating kidney } \\
\text { and prevent prostate cancer. It can be used for drinks, soups, } \\
\text { cakes and ice-creams. }\end{array}$ & $\begin{array}{l}\text { Aruquipa et al. 2017; } \\
\text { MeltingPot, 2017 }\end{array}$ \\
\hline
\end{tabular}


Supplementary Table. Common or vernacular names of the Andean root and tuber crops considered in this review (for a wider list of local names, see: Hermann, 1997; Lim, 2015).

\begin{tabular}{ll}
\hline Scientific name & Vernacular (local) name \\
\hline Arracacia xanthorrhiza Bancr & Perú: Arracacha \\
& Ecuador: Arracacha, zanahoria blanca \\
& Bolivia: Arracacha, racacha \\
Tropaeolum tuberosum Ruíz \& Pav & Perú: Mashua, Añu \\
& Bolivia: Isaño \\
Pachyrhizus ahipa (Wedd.) Parodi (Wedd & Peru: Ahipa \\
& Ecuador: n.k. \\
& Bolivia: Ajipa, willo \\
\multirow{2}{*}{ Smallanthus sonchifolius (Poepp.) H.Rob } & Peru: Yacon, Llacon \\
& Ecuador: Yacon, Llacon \\
& Bolivia: Yacon, Aricoma \\
\hline
\end{tabular}



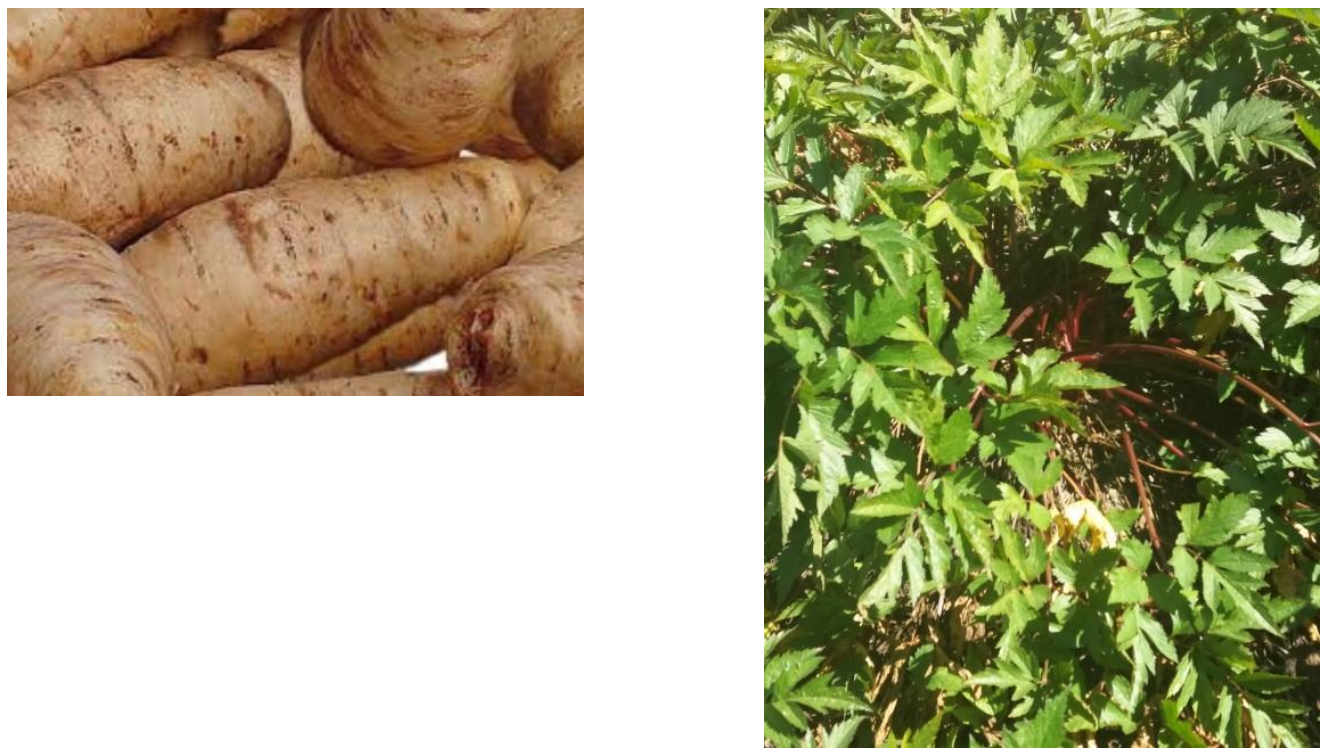

Figure 1. Tuberous roots of yellow arracacha (Pictures: L.A. Choquechambi and Katrine Mohr) 

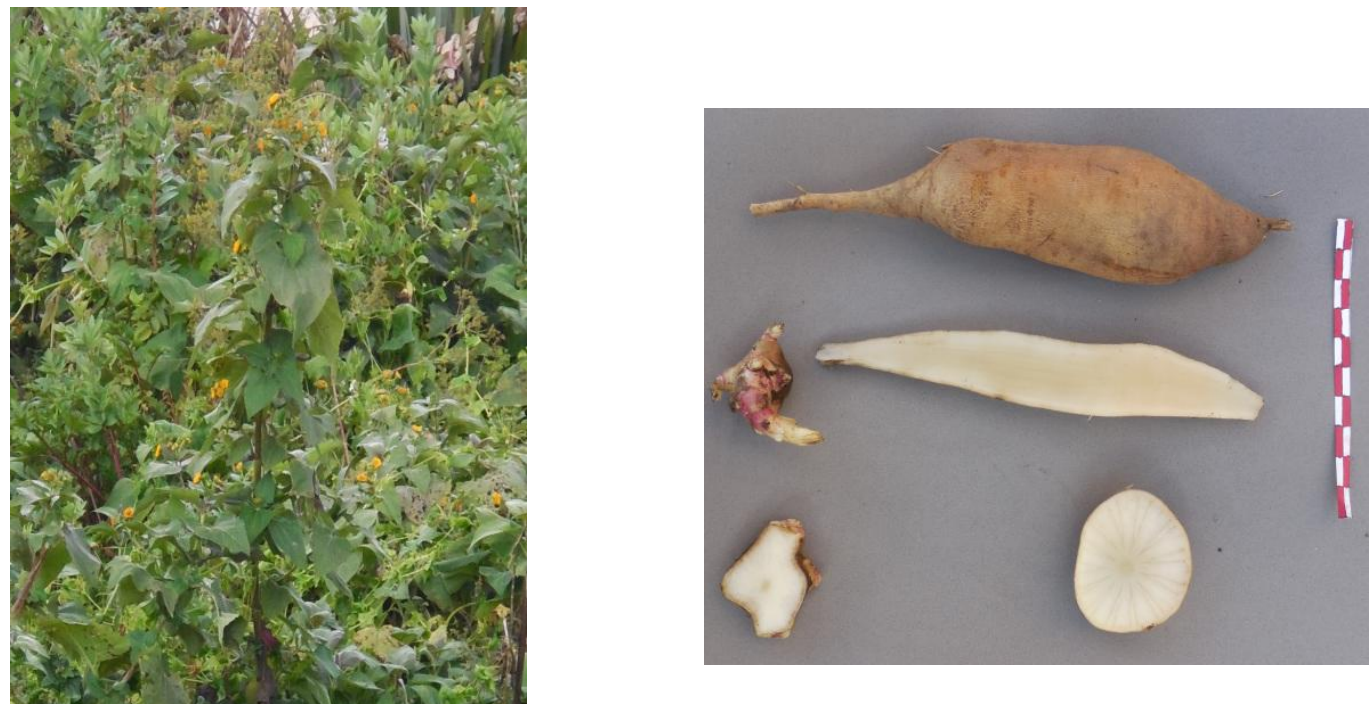

Figure 2. Field grown yacon and tuberous roots and corms of white yacon (Pictures: I.R. Callisaya). 

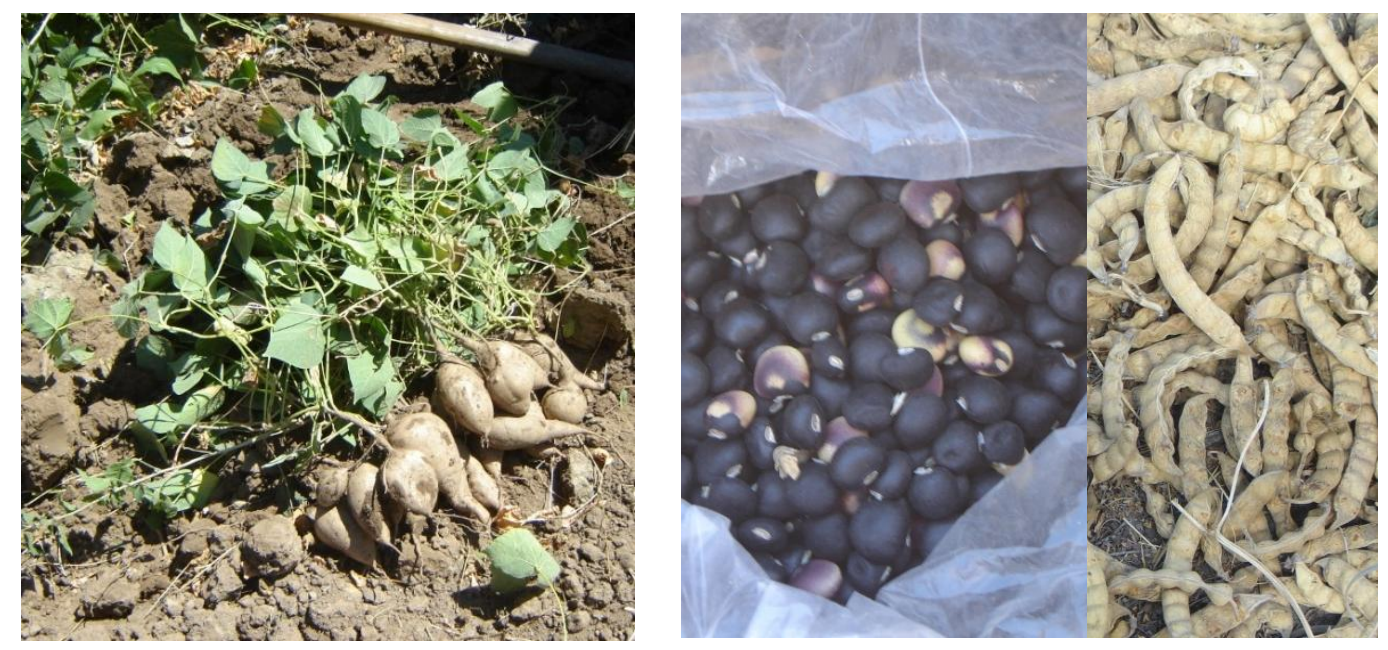

Figure 3. Plants with tuberous root of ahipa and dull black and yellowish white/black mottled seeds and pods (Pictures: J. P. Rodriguez). 

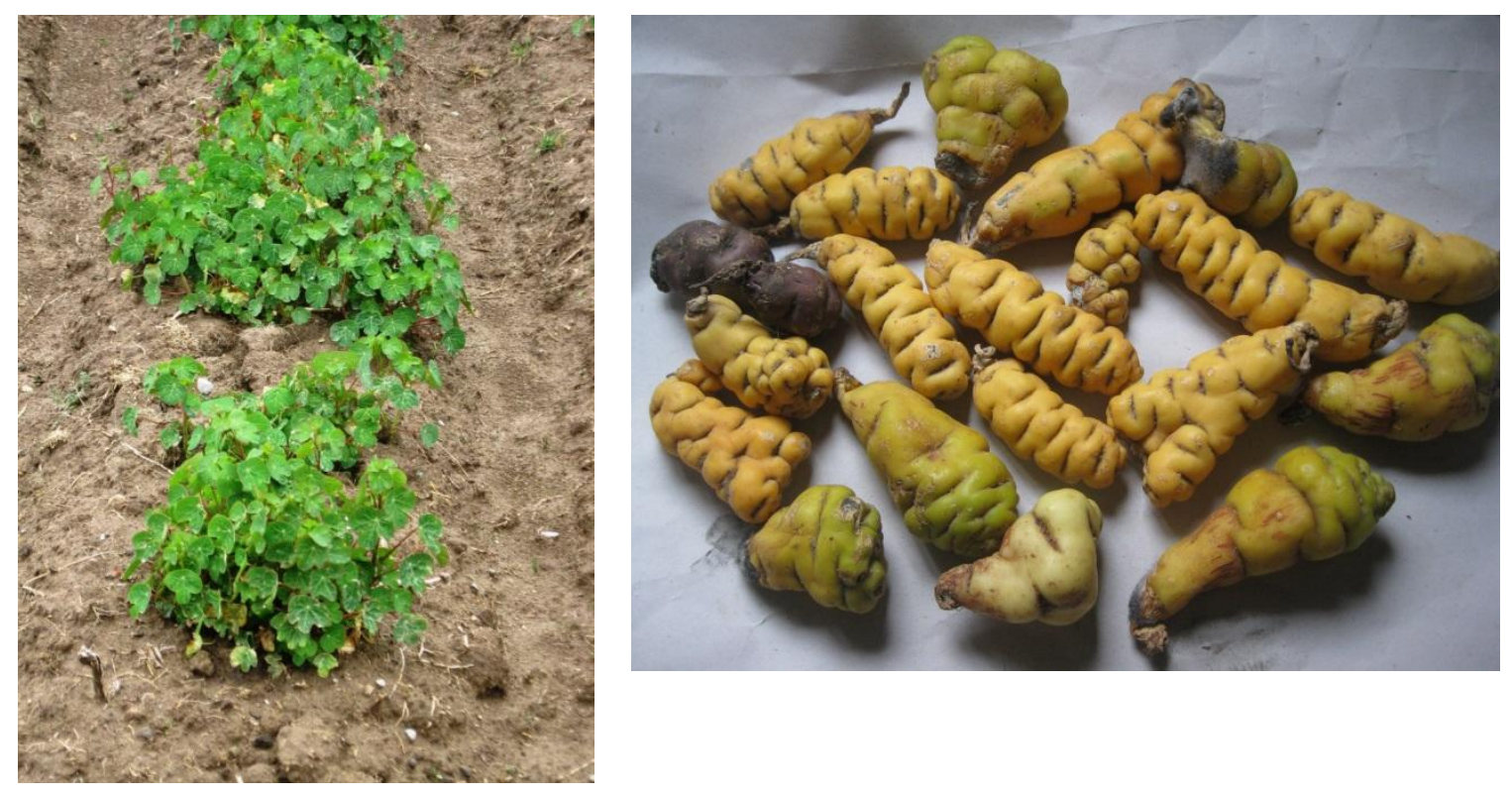

Figure 4. Plants of mashua growing in the field and tubers of different mashua varieties. (Pictures: E.O. Leidi) 


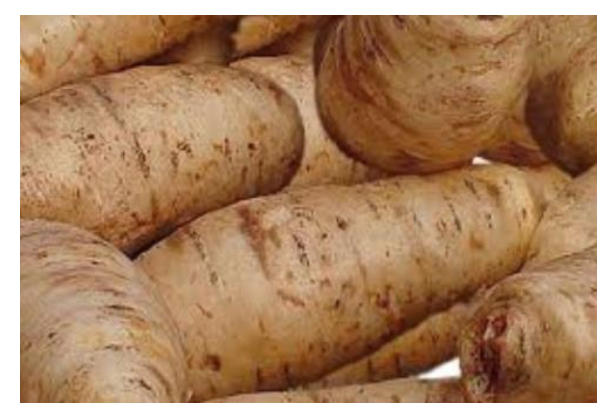

Arracacha: starch

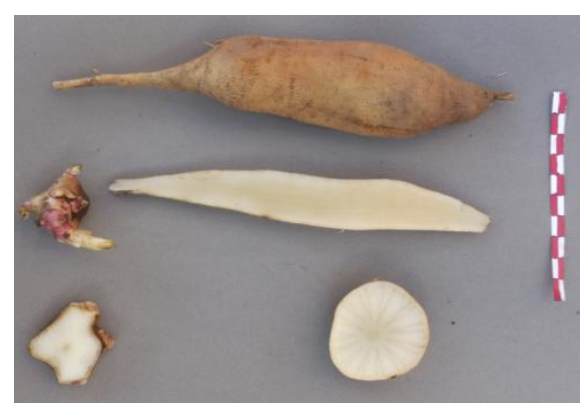

Yacon: fructoligosaccharides

Andean roots and tubers as sources of functional foods

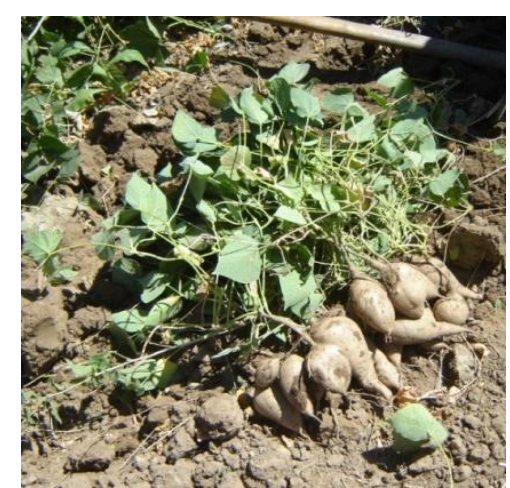

Ahipa: starch, sugars

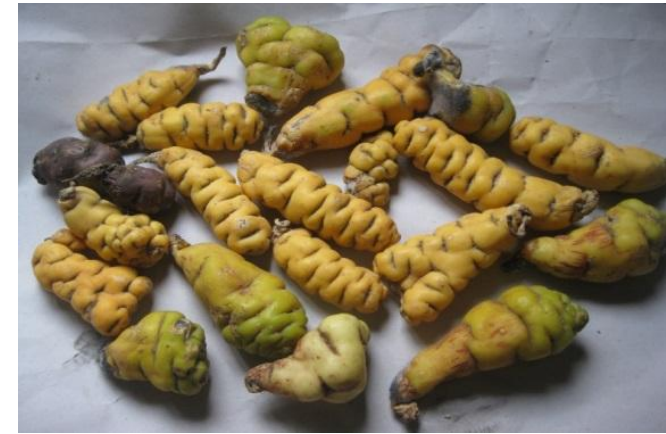

Mashua: starch, glucosinolates 
Conflicts of interest: None 


\section{Ethical Statement for Journal of Functional Foods}

I testify on behalf of all co-authors that our article submitted to Journal of Functional Foods:

Title: Andean roots and tubers as sources of functional foods

All authors: Eduardo O. Leidi, Alvaro Monteros Altamirano, Geovana Mercado,Juan Pablo Rodriguez, Alvaro Ramos, Gabriela Alandia, Marten Sørensen, Sven-Erik Jacobsen

1) this material has not been published in whole or in part elsewhere;

2) the manuscript is not currently being considered for publication in another journal;

3) all authors have been personally and actively involved in substantive work leading to the manuscript, and will hold themselves jointly and individually responsible for its content.

Date: June $6^{\text {th }} 2018$

Corresponding author's signature:

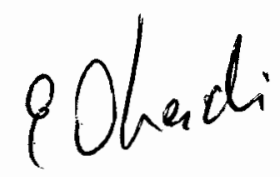

Eduardo O. Leidi 